\title{
How Tigger Inspired Intrepreneurship at Best Buy...and the Geek Squad
}

\author{
Sean Skelley
}

\begin{abstract}
KEYWORDS: Sales, Marketing, Advertising, Entrepreneurship, Marketing, Product Development.
\end{abstract}

In the late 1990's and into the early part of this century, computers didn't work well. They had software issues, hardware issues, customer knowledge problems and long hold lines if you could even figure out where to call. Manufacturers and the software companies blamed one another for the mess ... but at the end of the day, frustrated consumers turned to the retailers where they bought their computers for help.

This problem landed in my lap when I worked at Best Buy in 1998. Best Buy was developing a strategy around personal computers. The project was handed to me, in a manner of speaking, with a note attached that said, "fix this." As I delved into it I began to sense an opportunity that few others saw, and I had the itch to pursue it.

Whether you are a frontline employee, a manager, middle manager, executive or entrepreneur, you no doubt knew what came next. I didn't have enough gravitas to cause anyone to look twice. The CFO was not opening purse strings to give me resources. Talented colleagues on other teams were busy with their own goals and responsibilities and my project was not on their lists. Nobody believed in the culture that supported the work I wanted to do, or that it would add value to the work already being done. And oh yeah, there was this fictional scoreboard on the wall of my office with large blinking neon numbers that reminded me that $80 \%$ of internal and external innovation efforts . . fail.

When my small team of renegades and I took up the personal computer project, Best Buy stores had counters to help consumers deal with PC problems. It was affectionately (or maybe not-so-affectionately) called "the hole in the wall." We set out to turn that counter into an asset, but the experience was brutal. We continuously struggled for resources. We had to defend ourselves when others questioned whether our efforts

were needed at all. Floor space, a prized commodity in the world of retail, became a battleground. Policy restrictions inhibited our most innovative design ideas. Territorial conflicts, apparent cross-purposes, battles for mindshare, limitations in the ecosystem, difficult negotiations internally and externally, and a lawsuit thrown in for good measure...we faced them all.

But we managed to surmount these difficulties and launch a new unit of Best Buy that has become its celebrated Geek Squad, employing 20,000 people and generating $\$ 2$ billion in revenue each year. And we found inspiration from an unlikely hero: Tigger, Winniethe-Pooh's irrepressible friend.

\section{The Pressures on Intrepreneurs}

Sound bites don't do justice to the effort required to innovate. Geek Squad has been often described this way: "Best Buy acquired small Minneapolis company driving VW Beetles and drove it to cultural and commercial success." This sounds as if Best Buy just captured lightning in a bottle, and it gives short shrift to the herculean effort that made it happen. It's human nature to reduce a long and messy innovation process to a pithy statement, but my goal is to leave trail markers and footnotes for those in the throes of it. The journey is fraught with dangers, including the one that blindsides most intrapreneurs: the danger that comes when your innovation moves from a proof of concept stage, to becoming a viable business, product or service within the larger corporation.

As your carefully selected, nurtured and launched plan gets going - and should you be fortunate to have success - expect politics, battles, war for talent and go old fashioned petty jealousy, to come into play. Understand the dynamics and be ready for them. Know you will need protection and freedom long enough for 
your innovative virus to spread.

The 1990s was an interesting time at Best Buy. The company itself had scaled to new heights and had many, many projects underway. We realized very early on that Geek Squad was very different from the rest of Best Buy, which focused on doing many things at price and scale. At Geek Squad, we focused on doing only a few things at a premium. Best Buy had its own strong brand attributes: youthful and blue-shirted; a toy store for electronics and entertainment; and the top seller of music CD's at the time. Foot traffic through its doors was at an all-time high. In the midst of this, Best Buy was focused on changing to a more differentiated experience and delivering on more than just price.

But it clearly wasn't the entrepreneurial startup that Geek Squad was. Geek Squad had clarity of its brand (uniform, vernacular, technical skills, etc.) and Best Buy was going through a midlife crisis. It was clear who it was, but it wanted to be someone else.

A dog barks at what it doesn't understand. It needs to sniff, characterize the new stimuli and once it understands, it stops barking.

The notion of the maverick pioneer -- flying in the face of all forces against him or her, on the road to unbridled success -- simply doesn't happen most of the time. I realized quickly that Geek Squad would need to find common ground or it would become trampled by the force of the business around it.

That's when I hit upon the notion of Tigger, whom I came to know and appreciate through reading "Winnie the Pooh" to my daughters and watching the Disney films.

\section{Why Companies are Like the Hundred Acre Wood}

Look beyond the charm of a simple children's story like Winnie the Pooh, and you can see many levels of meaning that can inspire your team and even the broader organization.

For example, few people know Tigger is the only character not in the first A.A. Milne story. He was introduced in the second book. This creates a perfect parallel to startups inside a larger corporation, and I used that analogy to inspire our team.

You can almost assign the cast of characters in Pooh's Hundred Acre Wood to functions in a corporate structure. Kanga is HR; Owl is Senior Leadership; Piglet is Finance; Eyeore is Legal; and Rabbit plays the role of the core business to Tigger's entrepreneur spirit. In one Pooh episode, Rabbit attempts to take away Tigger's bounce because he doesn't like the disorder Tigger creates when he bounces. This is the common challenge in a new business within a big business. New business is different and the "core" looks at it like Rabbit looks at Tigger.

Tigger, the character, is similar to any startup. He has the rebellious attitude that he can do anything. Tigger claims that he likes everything (though it is quickly proven he does not like honey, acorns, thistles, or most of the contents of Kanga's larder.) Like new businesses, he thinks he can do anything better than anyone else. Such brashness is essential, and it's not meant to be a challenge to others. Instead, it's a youthful attitude. Think of a young child who thinks he/she can do anything but won't try new food. New opportunities are always exciting. Startups have a lot of what a friend calls "Name It/Claim It Economics:" "This is a $\$ 20$ billion industry! If we can get one percent we're a $\$ 200$ million business! C'mon, we can get 1 percent!" It's an intoxicating energy, but most startups are naïve to the actual challenges.

Follow the Tiggerism at this stage....as Tigger says "I like everything:"

- You need to be able to imagine and leverage endless bounces! Rather than the numerous business school models, this process is instinctual and it needs to be flexible and quick.

- Have the desire to tear apart the bigger business and expose opportunities and challenges.

- Tigger doesn't know his own strength and doesn't care. He pursues everything with passion and energy - which gives him strength. So should the intrapreneur.

- Be comfortable in exploring. Play endlessly and crash often. This cycle is critical, talentbased and calls for much political mapping.

\section{Tigger at Work}

I remember our early tests with Geek Squad. We took 
two of our agents and put them into a Best Buy store. This process wasn't typical. We tried to hire the employees temporarily so they wouldn't be an outsider to the others. But HR stated that if we hired them we couldn't afford to pay them enough because Best Buy had a rigid pay scale for associates.

We thought about this issue and came up with a simple solution. Best Buy would pay Geek Squad agents the "normal" pay scale - and we would pay a consultant fee to Geek Squad, which in turn would then pay their agents. It seems simple, but you need to find some innovative alternatives. Tigger's superpowers are real but not exactly what he thinks they are. It is noted in one story, "He always seems bigger because of his bounces," implying that other animals think of Tigger as being larger than he truly is. That's not a bad energy for a startup or intrepreneurial effort to exploit.

Another dimension of the Tigger persona is key to intrepreneurial efforts: Tigger is cheerful, outgoing, competitive in a friendly way, and has complete confidence in himself. Inside the hum of a major corporation, where necessary discipline and rigor can lead to premature rigormortis, the bounce has appeal and attracts others to lean in and see what's going on. This increases their energy to get things done.

Mind you, Tiggers sometimes exaggerate their abilities. In one Pooh episode, he claims that his superpowers include flying, jumping farther than a kangaroo, swimming and climbing trees. He never actually attempts any of the first three things in the course of the story, and he can climb a tree but can't climb down. He also claims that Tiggers "never get lost;" and unlike most of his other claims, this one seems to be true. He is able to find his way through the Forest even in a thick mist, despite Rabbit's attempts to lose him. Tiggers are always exciting, but many see them as competitive or crazy and then don't accept them. Intrapreneurs face the same perception problem.

\section{Spread the Excitement}

Innovators in a big company can feel like a chicken being plucked, a few feathers at a time. until it only has a few left. Unfortunately the chicken then becomes afraid of the inevitable so doesn't stand up for or push its uniqueness; instead it cocoons inward trying to stay alive.

We did something unique with Geek Squad to avoid that. We dispersed the 12 original "agents" into other Best Buy groups that had the same competency. So we took the agent responsible for mission control (the Geek Squad group that managed agents and customer calls) into the call center groups. The Geek Squad training agent was moved to Best Buy's training department.

This was one of our earliest big strategic plans. If we kept the 12 together they would soon be plucked, or marginalized for their Tigger-like enthusiasm and bounce. We instead put them in the other teams. This created a "virus" that inspired their new broader groups to think differently. This was critical to our success.

As mentioned, Tigger's personality is that he always overestimates (just like a great entrepreneur.) He had an aggressive personality and was clear on who he was (even if it was bravado.) He states that the accepting of challenges is one of the things Tiggers do best: "Tigger is the mother of Invention." Think about that line in the context of Tigger's character traits. Tigger is filled with great energy and optimism, and although well-meaning, he can also be mischievous, and his actions can lead to chaos and trouble.

\section{Say Things a New Way}

Another notable Tigger trait is mispronouncing words, stressing the wrong syllables. This is a direct corollary to a new business that is challenging the "core" words, and trying to see if a big or little change makes the "word" mean or do something. I wanted the Geek Squad team to emulate the attitude of "the bounce." I knew it was absolutely essential given the forces unfolding around us. Equally so, I felt it was critical for senior leadership to understand that "Tigger" could be perceived as a problem. After all, I didn't want the core characters trying to lose us in the Hundred Acre Wood.

One of the early things we did was help one of the Executive Vice Presidents with Geek Squad. He was having some technical issues and wanted to get his multiple PC's networking with one another. We sent out our very best agent, who processed the initial request along with several others, while at the executive's home. The internal senior leader was pleased with the service, but amazed at the price. He believed it was way too expensive (we had no "executive discount") and asserted that no consumer would buy the service at the rates we were charging. The episode reminded us that we would be tap dancing around multiple political issues every day, and would have some real issues to resolve. 
It's important to keep your focus despite such setbacks. And while senior executives can protect you from the wolves in the forest, don't make your intrepreneurial project the "Teacher's Pet" or it might change the outcome.

\section{Don't Lose Your Bounce}

To my mind Tigger's traits are absolutely key for an entrepreneur and perhaps even more so for the intrapreneur. People with traits like Tigger's are driven to innovate; it's an expression of who they are. So often you hear or read of companies with a mandate to innovate, and then the efforts stall. Without the unbounding energy (literally and figuratively) of your inner Tigger, leading and championing innovation will wear you out.

But be prepared - if you are successful in channeling your inner Tigger, you might wear out the members of the core business team. Enjoy this short clip, (https://www.youtube.com/watch?v=LRVzWYYWgxM) go back in time to childlike wonder, suspend all other thoughts for three minutes, and see what you pick up from this scene.

It's critical for a business within a business to realize they are Tigger. Their bounce is their differentiation and that differentiation can be a benefit, but also the biggest challenge.

In the midst of resistance to your innovative effort, remember to connect to your personal bounce. In the middle of the Geek Squad journey an artist created a picture of Tigger in a strait jacket, and the Best Buy house in the background, symbolizing the restriction the core business can place on the emerging new business. Take care to nourish the drive you have to create. Spend some time in quiet reflection, narrating your story as though reading a children's book. You'll be surprised how the exaggerated simplicity helps you identify, and hopefully renew, your bounce.

And consider this: It's not that Innovation demands enthusiasm and boundless energy; it's more that enthusiasm and boundless energy demands Innovation. You need an authentic bounce. 